\title{
Renal changes in COVID-19 infection
}

\author{
Pastora Maria de Araújo Duarte \\ Drancisco André Gomes Bastos Filho ${ }^{2}$ \\ (D) João Vitor Araujo Duarte ${ }^{2}$ \\ (i) Beatrice Araújo Duarte 2 \\ (iD) Isabella Araujo Duarte ${ }^{2}$ \\ Romélia Pinheiro Gonçalves Lemes ${ }^{3}$ \\ (iD) Fernando Barroso Duarte
}

1. Nefrologista no Hospital Walter Cantídio- Universidade Federal do Ceará, Fortaleza, CE, Brasil. 2. Graduandos do Curso de Medicina - Universidade Christus, Fortaleza, CE, Brasil. 3. Docente do Departamento de Análises Clínicas e Toxicológicas (DACT) - Universidade Federal do Ceará, Fortaleza, CE, Brasil. 4. Docente do Departamento de Cirurgia, Universidade Federal do Ceará, Fortaleza, CE, Brasil.

\section{SUMMARY}

The COVID-19 (SARS-CoV-2) infection started in China, Wuhan City, Hubei Province, in December 2019, and it was declared a pandemic in mid-March 2020, caused by a new coronavirus strain called SARS-CoV-2. The pathogenesis of kidney injury attributed to SARSCoV-2 is not well defined yet. Observations show that the kidney damage caused by the new virus mutation is mainly tubular, with impairment of glomerular filtration and high levels of urea and creatinine. A study with seriously ill patients with COVID-19 showed that acute kidney injury was present in $29 \%$. In the face of this evidence, based on recent studies, we can see the great renal contribution as an impact factor in the evolution of COVID-19, not just as a complicator of severity, but maybe part of the initial cascade of the process, requiring a deeper analysis using conventional biomarkers of kidney injury and more aggressive clinical intervention in patients at risk, in an attempt to reduce mortality.

KEYWORDS: Acute kidney injury. Infections. Coronavirus Infections/physiopathology. Betacoronavirus.

\section{INTRODUCTION}

The COVID-19 (SARS-CoV-2) infection started in China, Wuhan City, Hubei Province, in December 2019, and it was declared a pandemic in mid-March 2020 , caused by a new coronavirus strain called SARSCoV-2, with single-stranded RNA, positive sense and characterized by the initial appearance of a respiratory syndrome, ranging from a simple flu-like syndrome to severe respiratory insufficiency, with a high mortality rate in specific groups. It constitutes an entity with a strong impact on human health, with more than 2 million people affected, thus requiring efforts in understanding its diagnosis and therapy. Despite the greater respiratory, immune, and hematopoietic impairment, other organs seem to be involved, among them, the renal and cardiovascular system are not only part of the inflammatory storm, but also intrinsic targets of the virus. Heart failure and acute kidney injury are complications widely described in patients with more severe disease progression and requiring intensive care, in most reports. 


\section{DISCUSSION}

The pathogenesis of kidney injury attributed to SARS- CoV-2 is not well defined yet, but it seems to be multifactorial, involving mechanisms related to systemic hypoxia, coagulation abnormalities, sepsis, with a high release of cytokines, or even cell destruction due to virosis'. The virus shows tropism by the angiotensin 2-converting enzyme receptor (ACE 2), connecting to it through protein S (Spike protein), present in its skeleton, which promotes its entry into the cell and its cytopathic action. Besides that, the virus has an inhibitory effect on the enzyme, interfering in cytoprotective actions. This receptor is expressed in the lungs, kidneys, heart, and intestine. In the kidneys, it is found mainly in the proximal tubules and podocytes and in an amount 100 times greater than in the lungs; however, without description in the glomerulus or mesangium. Unlike SARS-CoV, which occurred in 2002, when it was suggested that renal impairment would probably be related to multiple organ failure, in SARS-CoV-2, the viral capsid nucleus protein was examined in situ post-mortem in the kidney, and it was discovered that the SARS-CoV-2 antigens accumulated in the renal tubules, suggesting that SARSCoV-2 directly infects the human kidney, inducing acute kidney injury (AKI) and contributing to viral spread in the body. At light microscopy, diffuse proximal tubular lesion, loss of brush border, non-isometric vacuolar degeneration, and even frank necrosis were observed. There was no description of vasculitis, interstitial inflammation, or hemorrhage ${ }^{2}$. The difference between the greater renal tropism of SARS$\mathrm{CoV}-2$ in relation to SARS-CoV can be explained by the increased affinity of SARS-CoV-2 with ACE2, allowing greater infection of the kidney, which can act as viral reservoir ${ }^{3-5}$. Previous studies have also shown that the SARS-CoV-2 infection can induce lymphopenia and, simultaneously, increase the number of inflammatory cytokines (cytokine storm) ${ }^{6}$. The AKI has been described in previous studies of SARS and MERS-CoV infections with occurrence in 5-15\% of the cases, and mortality of $60-90 \%$ in that group. In COVID-19, an average incidence of 3-9\% of AKI has been reported but maintaining a still high mortality rate and suggesting an important role of renal impairment and in the evolution of the disease, as well as alerting the need for early screening for renal changes ${ }^{1}$. Observations show that the kidney damage caused by the new virus mutation is mainly tubular, with impairment of glomerular filtration and high levels of urea and creatinine ${ }^{7,8}$. A study of 701 patients with COVID-19 from Tongii Hospital, affiliated with the University's Tongji School of Medicine Huazhong Science and Technology Institute, showed that $44 \%$ of patients had proteinuria and hematuria, $26.9 \%$ had hematuria alone, $14.1 \%$ had an increase in nitrogen slags, and 3.2\% met Kidney Disease Improving Global Outcomes (KDIGO) criteria for acute kidney injury. The authors concluded that kidney damage was an independent risk factor for death and that the greater the proteinuria and hematuria, the greater the risk of death ${ }^{5}$. Another study with 58 seriously ill patients with COVID-19 showed that acute kidney injury was present in $29 \%{ }^{9}$. In New York, 1,150 patients were observed for a period of 30 days (03/02/2020 to 04/01/2020) and showed that 257 (22\%) had critical status, with $29 \%$ of these evolving to AKI and renal replacement therapy ${ }^{10}$. In Wuhan, an observational study with 147 patients with severe respiratory failure who evolved to AKI presented, by Cox's univariate analysis, risk of death 5.3 times greater than those without kidney injury ${ }^{11}$.

\section{CONCLUSION}

In the face the evidence presented, based on recent studies, we can see the great renal contribution as an impact factor in the evolution of COVID-19, not just as a complicator of severity, but maybe as part of the initial cascade of the process, requiring a deeper investigation using conventional biomarkers of kidney injury and more aggressive clinical intervention in patients at risk, in an attempt to reduce mortality through the optimization of hemodynamics, research of drugs with evidence of nephroprotective action, immunomodulators, in addition to the guidelines already established for patient management.

\section{Author's Contribution}

All authors have contributed equally to the work 


\section{RESUMO}

Infecção pelo COVID-19 (SARS-CoV-2) começou na China, cidade de Wuhan, província de Hubei, em dezembro de 2019, e foi declarada pandemia em meados de março de 2020, causada por uma nova cepa de coronavírus chamada SARS-CoV-2. A patogênese da lesão renal atribuída à SARS-CoV-2 ainda não está bem definida. Observações mostram que o dano renal causado pela nova mutação viral é principalmente tubular, com comprometimento da filtração glomerular e apresentação de altos níveis de uréia e creatinina. Estudo com pacientes gravemente enfermos com COVID-19 mostrou que a lesão renal aguda estava presente em 29\%. Diante dessas evidências, com base em estudos recentes, podemos ver a grande contribuição renal como um fator de impacto na evolução do COVID-19, não apenas como um complicador da gravidade, mas talvez como parte da cascata inicial do processo, exigindo uma investigação de análise mais profunda usando biomarcadores convencionais de lesão renal e intervenção clínica mais agressiva em pacientes em risco, na tentativa de reduzir a mortalidade.

PALAVRAS-CHAVE: Lesal renal aguda. Infecções. Infecções por coronavirus/fisiopatologia. Betacoronavirus.

\section{REFERENCES}

1. Naicker S, Yang CW, Hwang SJ, Liu BC, Chen JH, Jha V. The novel coronavirus 2019 epidemic and kidneys. Kidney Int. 2020;97(5):824-8.

2. Su H, Yang M, Wan C, Yi LX, Tang F, Zhu HY, et al. Renal histopathological analysis of 26 postmortem findings of patients with COVID-19 in China. Kid Int. 2020;98(1):219-27.

3. Chu KH, Tsang WK, Tang CS, Lam MF, Lai FM, To KF, et al. Acute renal impairment in coronavirus-associated severe acute respiratory syndrome. Kidney Int. 2005;67(2):698-705.

4. Diao B, Wang C, Wang R, Feng Z, Tan Y, Wang H, et al. Human kidney is a target for novel severe acute respiratory syndrome coronavirus 2 (SARSCoV-2) infection. medRxiv 2020.03.04.20031120. doi: https://doi.org/10.1 101/2020.03.04.20031120.

5. Pan XW, Xu D, Zhang H, Zhou W, Wang LH, Cui XG. Identification of a potential mechanism of acute kidney injury during the COVID-19 outbreak: a study based on single-cell transcriptome analysis. Intensive Care Med. 2020;46(6):1114-6.
6. Huang C, Wang Y, Li X, Ren L, Zhao J, Hu Y, et al. Clinical features of patients infected with 2019 novel coronavirus in Wuhan, China. Lancet. 2020;395(10223):497-506

7. Hui DSC, Zumla A. Severe acute respiratory syndrome: historical, epidemiologic, and clinical features. Infect Dis Clin North Am. 2019;33(4):869-89.

8. Joob B, Wiwanitkit V. Novel Middle East respiratory syndrome and renal failure. Ren Fail. 2014;36(1):147.

9. Yang $X, Y u Y, X u$ J, Shu $H$, Xia J, Liu H, et al. Clinical course and outcomes of critically ill patients with SARS-CoV-2 pneumonia in Wuhan, China: a single-centered, retrospective, observational study. Lancet Respir Med. 2020;8(5):475-81.

10. Cummings MJ, Baldwin MR, Abrams D, Jacobson SD, Meyer BJ, Balough EM, et al. Epidemiology, clinical course, and outcomes of critically ill adults with COVID-19 in New York City: a prospective cohort study. MedRxiv. 2020;2020.04.15.20067157.

11. Li Z, Wu M, Yao J, Guo J, Liao X, Song S, et al. Caution on kidney dysfunctions of COVID-19 patients. medRxiv 2020.02.08.20021212. doi: https:// doi.org/10.1101/2020.02.08.20021212. 